\title{
Biomarkers of inflammation, metabolism, and oxidative stress in blood, liver, and milk reveal a better immunometabolic status in peripartal cows supplemented with Smartamine M or MetaSmart
}

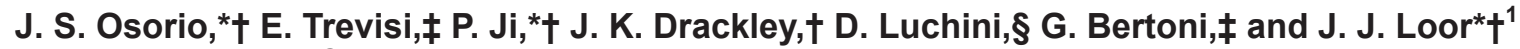 \\ *Mammalian NutriPhysioGenomics, and \\ †Department of Animal Sciences and Division of Nutritional Sciences, University of Illinois, 1207 West Gregory Drive, Urbana 61801 \\ łIstituto di Zootecnica, Facoltà di Agraria, Università Cattolica del Sacro Cuore, 29122 Piacenza, Italy \\ §Adisseo, Alpharetta 30022, GA
}

\section{ABSTRACT}

The peripartal dairy cow experiences a state of reduced liver function coupled with increased inflammation and oxidative stress. This study evaluated the effect of supplementing basal diets with rumen-protected Met in the form of MetaSmart (MS) or Smartamine M (SM) (both from Adisseo Inc., Antony, France) during the peripartal period on blood and hepatic biomarkers of liver function, inflammation, and oxidative stress. Thirty-seven multiparous Holstein cows were fed the same basal diet from -50 to $-21 \mathrm{~d}$ relative to expected calving $[1.24 \mathrm{Mcal} / \mathrm{kg}$ of dry matter (DM); no Met supplementation]. From $-21 \mathrm{~d}$ to calving, the cows received diets (1.54 Mcal $/ \mathrm{kg}$ of $\mathrm{DM})$ with no added Met (control, CON; $\mathrm{n}=13)$, CON plus MS $(\mathrm{n}=11)$, or CON plus SM $(\mathrm{n}=13)$. From calving through $30 \mathrm{~d}$ in milk (DIM), the cows received the same postpartal diet (1.75 Mcal/kg of DM; CON), or CON plus MS or CON plus SM. Liver and blood samples were harvested at various time points from -21 to $21 \mathrm{~d}$ relative to calving. Preplanned contrasts of CON versus SM + MS during prepartum ( -21 and $-10 \mathrm{~d}$ before calving) and postpartum (7, 14, and $21 \mathrm{~d}$ after calving) responses were evaluated. Cows fed MS or SM compared with CON had lower overall concentrations of plasma ceruloplasmin and serum amyloid A (SAA). Compared with CON, Met-supplemented cows had greater overall plasma oxygen radical absorbance capacity. Liver concentrations of glutathione and carnitine also were greater overall with Met supplementation. Milk choline and liver phosphatidylcholine were lower overall in cows fed Met compared with controls. Liver tissue choline concentrations did not differ. Data indicate that supplemental Met enhanced de novo glutathione and carnitine synthesis in liver and, thus, increased antioxidant and $\beta$-oxidation capacity. The greater decrease of

Received November 4, 2013

Accepted September 1, 2014.

${ }^{1}$ Corresponding author: jloor@illinois.edu
IL-6 after calving coupled with lower ceruloplasmin and SAA in Met-supplemented cows indicated a reduction in proinflammatory signaling within liver. The lower hepatic phosphatidylcholine in Met-supplemented cows might have been associated with greater assembly or export of very low density lipoproteins. Overall, biomarker analyses in blood and tissue indicate that the beneficial effect of feeding SM and MS on postpartal cow performance is due in part to a better immunometabolic status.

Key words: animal health, transition period, nutrition, lactation

\section{INTRODUCTION}

Research in ruminant animals supports the hypothesis that increasing the supply of Met could enhance the capacity of liver to export triacylglycerol (TAG) in the form of very low density lipoproteins (VLDL; Durand et al., 1992; Auboiron et al., 1994, 1995) and help ameliorate the negative effects of fatty acid accumulation in the liver soon after parturition (Drackley, 1999). Within liver, Met also can be transformed into S-adenosylmethionine (SAM), the most important methyl donor (Martinov et al., 2010), and in turn SAM can be used to methylate phosphatidylethanolamine (PE) to produce phosphatidylcholine (PC), which is a main constituent of VLDL. Besides the methylation of PE, SAM also is involved in methylation of DNA, a process that has profound regulatory effects on gene expression (Kass et al., 1997).

The peripartal dairy cow experiences a state of reduced liver function coupled with increased inflammation and oxidative stress (Bionaz et al., 2007; Trevisi et al., 2012). Bilirubin, glutamic-oxaloacetic transaminase (GOT), $\gamma$-glutamyltransferase (GGT) along with albumin and paraoxonase (PON) are commonly used biomarkers of liver status around calving (Bertoni et al., 2008). The liver is responsible for clearance of bilirubin (Bertoni et al., 2008), and higher GOT and GGT are related to liver cell damage (i.e., lysis and necrosis). 
The peripartal inflammatory response is characterized by an increase in the production of positive acutephase proteins (posAPP) such as haptoglobin and serum amyloid A (SAA) and a concomitant decrease in the production of negative APP (negAPP) such as albumin (Bertoni et al., 2008). At the level of liver, the well-established triggers of these responses are the proinflammatory cytokines IL-6, IL-1, and tumor necrosis factor (TNF)- $\alpha$ (Kindt et al., 2007). Bacterial contamination of the uterus after calving also contributes to the release of TNF- $\alpha$ and IL-6 (LeBlanc, 2012). The concentrations of these cytokines in turn are driven by several factors, including tissue damage, pathogen invasion, and potentially excessive fat deposition (O'Boyle et al., 2006; Loor et al., 2013a). The uterus can secrete prostaglandin $\mathrm{F}$ (during calving) and prostaglandin $\mathrm{E}$ (in response to bacteria), both of which can further stimulate the proinflammatory response and contribute to greater reactive oxygen metabolites (ROM) concentrations in circulation (Haeggström and Funk, 2011; LeBlanc, 2012).

Oxidative stress is driven by the imbalance between the production of ROM and the neutralizing capacity of antioxidant mechanisms in tissues and in blood. Some of the well-established antioxidants include glutathione, superoxide dismutase (SOD), and vitamins $\mathrm{A}$ and E (Bernabucci et al., 2005). Additionally, the concentration of PON is inversely related to oxidative stress partly because it helps protect both low-density lipoprotein (LDL) and high-density lipoprotein (HDL) against lipid peroxidation (Aviram and Rosenblat, 2004).

Our general hypothesis was that rumen-protected Met supplementation in the form of MetaSmart (MS) and Smartamine (SM) (both from Adisseo Inc., Antony, France) during the peripartal period ameliorates the negative effects of peripartal adipose tissue lipolysis that often leads to excessive liver TAG accumulation and, consequently, places cows at greater risk of developing ketosis (Osorio et al., 2013). As such, supplemental Met would have a positive effect on liver function, inflammation, and oxidative stress status. Blood serum and plasma from cows fed MS and SM (Osorio et al., 2013) were used to address this hypothesis. Concentrations of total bilirubin (TB), GGT, GOT, cholesterol, and PON were used to assess liver function and integrity; creatinine and urea to evaluate skeletal muscle catabolism; ceruloplasmin, SAA, haptoglobin, and IL-6 to assess inflammation status; and concentrations of nitric oxide $(\mathbf{N O x})$ and constituents [nitrite $\left(\mathrm{NO}_{2}{ }^{-}\right)$and nitrate $\left(\mathrm{NO}_{3}^{-}\right)$], oxygen radical absorbance capacity (ORAC), ROM, retinol, tocopherol, $\beta$-carotene, and liver glutathione to assess oxidative stress status.

\section{MATERIALS AND METHODS}

\section{Animals, Experimental Design, and Dietary Treatments}

The Institutional Animal Care and Use Committee (IACUC) of the University of Illinois approved all protocols for this study (protocol no. 09214). Details of the experimental design have been published previously (Osorio et al., 2013). Briefly, 37 multiparous Holstein cows were fed experimental treatments consisting of a basal control diet ( $\mathrm{CON}, \mathrm{n}=13$ ) with no Met supplementation, CON plus MS $(\mathrm{n}=11)$ at a rate of $0.19 \%$ of DM, and CON plus SM ( $\mathrm{n}=13)$ at a rate of $0.07 \%$ of DM. All cows received the same far-off diet from -50 to $-21 \mathrm{~d}$ relative to expected calving $(1.24 \mathrm{Mcal} / \mathrm{kg}$ of DM, RDP at $10.3 \%$ of DM, RUP at $4 \%$ of DM, Lys at $7.3 \%$ of MP, and Met at $1.87 \%$ of MP), the same closeup diet from $-21 \mathrm{~d}$ to expected calving $(1.54 \mathrm{Mcal} / \mathrm{kg}$ of DM, RDP at $10 \%$ of DM, RUP at $5.1 \%$ of DM, Lys at $6.66 \%$ of MP, and Met at $1.86 \%$ of MP), and from calving through 30 DIM $(1.75 \mathrm{Mcal} / \mathrm{kg}$ of DM, RDP at $10.9 \%$ of DM, RUP at $6.5 \%$ of DM, Lys at $6.17 \%$ of MP, and Met at $1.81 \%$ of MP). From -21 d to parturition, Met supplements were top-dressed to increase Met in MP from $1.86(\mathrm{CON})$ to 2.35 (MS) and 2.38\% (SM). From calving to 30 DIM, Met supplements were top-dressed to increase Met in MP from $1.81(\mathrm{CON})$ to $2.15 \%$ (MS and SM).

As described in Osorio et al. (2013), all cows before calving were individually fed once daily at 0630 $\mathrm{h}$ using an individual gate system (American Calan, Northwood, NH). Cows were housed in a ventilated, enclosed barn during the dry period and had access to sand-bedded freestalls until $3 \mathrm{~d}$ before expected parturition, when they were moved to individual maternity pens bedded with straw until parturition. After parturition, cows were housed in a tiestall barn, fed a common lactation diet once daily, and milked $3 \times$ daily.

\section{Blood, Liver, and Milk Samples, and Biomarker Analyses}

Details of the methodologies have been published previously (Osorio et al., 2013); in brief, blood was sampled from the coccygeal vein using a 20-gauge BD Vacutainer needle (Becton Dickinson, Franklin Lakes, NJ) at $-25,-21,-10,7,14$, and 21 d relative to calving. Blood was collected into Vacutainers $(5 \mathrm{~mL}, \mathrm{BD}$ Vacutainer, Becton Dickinson) containing either serum clot activator or lithium heparin.

Liver was sampled via puncture biopsy (Dann et al., 2006) from cows under local anesthesia at approximately $0730 \mathrm{~h}$ on $\mathrm{d}-10,7$, and 21 relative to parturition. 
Tissue specimens were stored in liquid $\mathrm{N}_{2}$ until further analysis.

Consecutive morning, midday, and evening milk samples were collected once a week every Wednesday until 30 DIM. Composite milk samples were prepared in proportion to milk yield at each milking and stored at $-20^{\circ} \mathrm{C}$ until further analysis.

Blood samples were analyzed for albumin, cholesterol, TB, creatinine, urea, GOT, haptoglobin, ceruloplasmin, PON, NOx, $\mathrm{NO}_{2}^{-}, \mathrm{NO}_{3}^{-}$, ROM, and GGT using kits purchased from Instrumentation Laboratory (Lexington, MA) following the procedures described previously (Bionaz et al., 2007; Trevisi et al., 2012) using a clinical auto-analyzer (ILAB 600, Instrumentation Laboratory). Total antioxidants were assessed through the ORAC assay. This method measures a fluorescent signal from a probe (fluorescein) that decreases in the presence of radical damage (Cao and Prior, 1999).

Bovine IL-6 plasma concentration was determined by a colorimetric sandwich ELISA using a Bovine IL-6 Screening Set (\#ESS0029 Endogen, Pierce, Rockford, IL). Coefficients of variation within and between assays were 3.5 and $13.4 \%$, respectively. The kit is designed for the analysis of cell culture supernatants. Validation of the kit for bovine plasma was performed via spike-in recovery assessment (R\&D Systems Inc., Minneapolis, MN; spike and recovery Immunoassay Sample Validation Protocol), and linearity testing. The observed, compared with expected, cytokine concentrations were in the 85 to $120 \%$ range. The bovine plasma volume used for the assay required a 2 -fold dilution at least.

Liver tissue free carnitine (cat. no. K642-100; BioVision Inc., Milpitas, CA), PC (cat. no. K576-100; BioVision Inc.), and choline (cat. no. K576-100; BioVision Inc.) were measured at 7 and $21 \mathrm{~d}$ postpartum using commercial kits, whereas liver glutathione (cat. no. NWK-GSH01; Northwest Life Science Specialties LLC, Vancouver, WA) was quantified at $-10,7$, and $21 \mathrm{~d}$ relative to parturition. The concentration of milk choline was determined at wk 3 postpartum using a commercial kit (cat. no. KA1662; Abnova, Taipei City, Taiwan).

\section{Statistical Analysis}

The data of blood and liver metabolites were analyzed with the PROC MIXED of SAS 9.3 (SAS Institute Inc., Cary, NC). The fixed effects in the model included diet $(\mathrm{D})$, time $(\mathrm{T})$, and their interaction $(\mathrm{D} \times \mathrm{T})$. The random effect was cow nested within treatment. Unequally spaced data were analyzed using the exponential correlation covariance structure SP for repeated measures. Blood results obtained at $-25 \mathrm{~d}$ for various biomarkers were used as covariates. Least squares means separation between time points was performed using the PDIFF statement. Statistical significance was declared at $P \leq$ 0.05 and tendencies at $P \leq 0.15$.

\section{RESULTS}

\section{Biomarkers of Muscle Mass Catabolism and N Metabolism}

Main effects of diet, time, and interactions are presented in Table 1. Unlike that of urea, the concentration of creatinine showed a trend for an interaction $(P$ $=0.10)$ of diet $\times$ time $(\mathrm{D} \times \mathrm{T})$ that resulted from a greater $(P<0.05)$ concentration at $7 \mathrm{~d}$ in $\mathrm{CON}$ cows compared with MS + SM (Figure 1A). Although overall concentration of urea was affected $(P=0.005)$ only by time (Figure 1B), this was mainly driven by a postpartal time effect $(P<0.01$; Supplemental Table S1; http://dx.doi.org/10.3168/jds.2013-7679) where urea reached nadir levels at $14 \mathrm{~d}$ postpartum.

\section{Biomarkers of Liver Function}

Main effects of diet, time, and interactions are presented in Table 1 . The interaction $\mathrm{D} \times \mathrm{T}$ was not significant $(P>0.05)$ for any of the liver function biomarkers. Among the biomarkers related to liver function, only albumin showed a trend $(P=0.15)$ for greater concentration in Met-supplemented cows compared with CON. In fact, postpartal albumin tended to be greater $(P<0.06)$ in Met-supplemented cows than $\mathrm{CON}$, whereas this effect was not observed $(P=$ 0.69 ) during the close-up period (Table 2). The nadir of albumin at 7 and $14 \mathrm{~d}$ postpartum in CON cows confirmed the latter (Figure 2A). The concentration of TB (Figure 2B), GOT (Figure 2C), and cholesterol (Figure 2D) increased significantly over time $(P<0.01)$ after calving (Table 1). Although the concentration of GGT (Figure $2 \mathrm{E}$ ) was mainly affected by time $(P<0.01)$, we detected a trend for a diet effect $(P=0.11)$ postpartum (Supplemental Table S1; http://dx.doi.org/10.3168/ jds.2013-7679). That effect could be associated with a trend for greater concentration of GGT in SM over CON $(P=0.09)$ and MS $(P=0.06)$ cows. In contrast, PON (Figure 2F) was mainly affected by time $(P<$ 0.01 ) and reached nadir levels at $7 \mathrm{~d}$ postpartum.

\section{Biomarkers of Met Metabolism}

Main effects of diet, time, and interactions are presented in Table 1 . The $\mathrm{D} \times \mathrm{T}$ interaction was not significant $(P>0.05)$ for any of the Met metabolism biomarkers. Liver carnitine $(P<0.01)$ and glutathione $(P=0.04)$ were greater in Met-supplemented cows than in CON cows throughout the experiment, whereas 
Table 1. Effects of supplementing cows with MetaSmart (MS; Adisseo Inc., Antony, France) or Smartamine M (SM; Adisseo Inc.) during the peripartal period on blood, liver, and milk biomarkers

\begin{tabular}{|c|c|c|c|c|c|c|c|c|}
\hline Marker & \multicolumn{3}{|c|}{ Treatment diet } & $\mathrm{SEM}^{1}$ & \multicolumn{4}{|c|}{$P$-value } \\
\hline Creatinine $(\mu \mathrm{mol} / \mathrm{L})$ & 97.5 & 96.6 & 95.7 & 1.56 & 0.38 & 0.43 & $<0.01$ & 0.10 \\
\hline Urea $(\mathrm{mmol} / \mathrm{L})$ & 4.87 & 4.87 & 4.87 & 0.19 & 0.70 & 0.97 & 0.005 & 0.90 \\
\hline \multicolumn{9}{|l|}{ Liver function } \\
\hline Total bilirubin ${ }^{3}(\mu \mathrm{mol} / \mathrm{L})$ & $0.88(1.84)$ & $0.58(1.49)$ & $0.57(1.48)$ & 0.49 & 0.66 & 0.70 & $<0.01$ & 0.97 \\
\hline GGT $(\mathrm{U} / \mathrm{L})$ & 24.9 & 24.1 & 27.2 & 2.26 & 0.61 & 0.78 & $<0.01$ & 0.48 \\
\hline PON $(\mathrm{U} / \mathrm{mL})$ & 64.9 & 68.3 & 63.6 & 3.74 & 0.64 & 0.80 & $<0.01$ & 0.81 \\
\hline \multicolumn{9}{|l|}{ Methionine metabolism } \\
\hline \multicolumn{9}{|l|}{ Milk } \\
\hline Choline (mg/L) & 38.3 & 26.5 & 29.0 & 4.9 & 0.13 & 0.04 & & \\
\hline \multicolumn{9}{|l|}{ Liver } \\
\hline Carnitine (nmol/g of tissue) & 37.5 & 98.2 & 66.0 & 14.2 & 0.01 & $<0.01$ & 0.52 & 0.31 \\
\hline Ceruloplasmin $(\mu \mathrm{mol} / \mathrm{L})$ & 3.02 & 2.68 & 2.71 & 0.10 & 0.03 & 0.009 & $<0.01$ & 0.67 \\
\hline $\mathrm{SAA}(\mu \mathrm{g} / \mathrm{mL})$ & 61 & 40.7 & 43.5 & 9.3 & 0.17 & 0.06 & 0.24 & 0.47 \\
\hline Haptoglobin $^{3}(\mathrm{~g} / \mathrm{L})$ & $-1.48(0.36)$ & $-1.70(0.31)$ & $-1.67(0.31)$ & 0.18 & 0.6 & 0.32 & 0.01 & 0.60 \\
\hline IL-6 $(\mathrm{pg} / \mathrm{mL})$ & 612.1 & 546.3 & 447.4 & 93 & 0.40 & 0.29 & $<0.01$ & 0.73 \\
\hline \multicolumn{9}{|l|}{ Oxidative stress } \\
\hline $\mathrm{ROM}\left(\mathrm{mg}\right.$ of $\left.\mathrm{H}_{2} \mathrm{O}_{2} / 100 \mathrm{~mL}\right)$ & 13.7 & 12.8 & 14.2 & 0.61 & 0.24 & 0.73 & $<0.01$ & 0.62 \\
\hline $\mathrm{ORAC}(\mathrm{mol} / \mathrm{L})$ & 11.9 & 12.9 & 12.4 & 0.29 & 0.05 & 0.04 & $<0.01$ & 0.66 \\
\hline $\mathrm{NOx}(\mu \mathrm{mol} / \mathrm{L})$ & 23.5 & 22.8 & 23.5 & 0.67 & 0.69 & 0.69 & $<0.01$ & 0.06 \\
\hline $\mathrm{NO}_{2}^{-}(\mu \mathrm{mol} / \mathrm{L})$ & 6.42 & 6.7 & 6.6 & 0.54 & 0.92 & 0.70 & $<0.01$ & 0.27 \\
\hline $\mathrm{NO}_{3}^{-}(\mu \mathrm{mol} / \mathrm{L})$ & 17 & 16.5 & 16.9 & 0.51 & 0.7 & 0.57 & $<0.01$ & 0.04 \\
\hline \multicolumn{9}{|l|}{ Vitamins } \\
\hline Retinol $(\mu \mathrm{g} / 100 \mathrm{~mL})$ & 40 & 37.7 & 42.3 & 2.3 & 0.40 & 0.98 & $<0.01$ & 0.06 \\
\hline Tocopherol $(\mu \mathrm{g} / \mathrm{mL})$ & 3.44 & 3.79 & 3.06 & 0.51 & 0.58 & 0.98 & $<0.01$ & 0.21 \\
\hline
\end{tabular}

${ }^{1}$ Greatest standard error of the mean.

${ }^{2}$ Contrast statement of control (CON) vs. MS+SM.

${ }^{3}$ Data were log-transformed before statistics. Back-transformed least squares means are shown in parentheses. The standard errors of the means associated with log-transformed data are in log scale.

milk choline was lower $(P=0.04)$ in Met-supplemented cows (Table 1). Similar to milk choline, liver PC tended to be lower $(P=0.07)$ in Met-supplemented cows (Table 1). Although liver choline was not affected by Met supplementation (Table 1$)$, we detected a trend ( $P$ $=0.06$ ) for an interaction, which was attributed mainly to an increase in liver choline concentration in $\mathrm{CON}$ cows from 7 to $21 \mathrm{~d}$ after calving, whereas the concentration in Met-supplemented cows remained unchanged (Figure 3).

\section{Biomarkers of Inflammation and Acute-Phase Proteins}

Main effects of diet, time, and interactions for inflammation and acute-phase protein (APP) biomarkers are presented in Table 1 . The interaction $\mathrm{D} \times \mathrm{T}$ was not significant $(P>0.05)$ for any of the inflammation or APP biomarkers. Unlike haptoglobin and IL-6, cerulo- plasmin (Figure 4A) showed an effect of diet $(P=0.03)$, specifically because of lower $(P=0.009)$ concentration in Met-supplemented diets (CON vs MS + SM). Similarly, SAA concentration (Table 1) tended to be lower $(P=0.06)$ in Met-supplemented cows than in CON. Although diet had no overall effect on IL-6 concentration (Table 1$)$, we detected a trend $(P=0.13)$ for lower postpartal IL-6 concentration in Met-supplemented cows compared with CON cows (Table 2).

\section{Biomarkers of Oxidative Stress}

Main effects of diet, time, and interactions for biomarkers related with oxidative stress are presented in Table 1. We observed a significant interaction of $\mathrm{D} \times \mathrm{T}$ for $\mathrm{NO}_{3}{ }^{-}(P=0.04)$ and to a lesser extent in NOx $(P=$ $0.06)$ concentration. These effects were associated with a greater $(P<0.05)$ concentration of NOx in CON versus MS + SM cows at $-21 \mathrm{~d}$ (Figure $5 \mathrm{~A}$ ), and a greater 
concentration of both $\mathrm{NOx}$ and $\mathrm{NO}_{3}^{-}$(Figure $5 \mathrm{~B} ; \mathrm{P}=$ 0.02 ) in $\mathrm{SM}$ versus $\mathrm{CON}$ at $7 \mathrm{~d}$ postpartum. However, we detected a trend for lower prepartal $\mathrm{NO}_{3}{ }^{-}$in Metsupplemented cows compared with CON. Unlike NOx and $\mathrm{NO}_{3}^{-}$, ORAC (Figure $5 \mathrm{C} ; \mathrm{P}=0.04$ ) was greater in $\mathrm{MS}$ and $\mathrm{SM}$ cows than in CON. Although ROM (Figure 5E) were only affected by time (Table 1), we observed a postpartal trend $(P=0.14)$ for a diet effect (Supplemental Table S1; http://dx.doi.org/10.3168/ jds.2013-7679), where the ROM concentration was greater $(P=0.05)$ in SM than in MS cows. The concentration of $\mathrm{NO}_{2}{ }^{-}$was mainly affected by time $(P<$ $0.01)$ and, similarly to $\mathrm{NOx}$, it reached nadir levels at $7 \mathrm{~d}$ postpartum.

\section{Vitamins}

Main effects of diet, time, and interactions for vitamins are presented in Table 1. Among vitamins, only retinol tended to be affected $(P=0.06)$ by the interaction of $\mathrm{D} \times \mathrm{T}$, due to an increase $(P<0.003)$ in $\mathrm{SM}$ at $21 \mathrm{~d}$ postpartum compared with other treatments (Figure 6A). Tocopherol and $\beta$-carotene were affected $(P$ $<0.01$ ) by time (Table 1 ) but only $\beta$-carotene showed a trend $(P=0.10)$ for greater postpartal concentration in Met-supplemented cows compared with CON (Supplemental Table S1; http://dx.doi.org/10.3168/ jds.2013-7679).

\section{DISCUSSION}

Supplementation with MS or SM improved milk production at least in part by increasing postpartal DMI and reducing liver lipid accumulation (Osorio et al., 2013). Postpartal negative energy balance in dairy cows is commonly associated with lower DMI with respect to the greater energy requirements for milk production. In the companion study, we observed that Met supplementation (SM or MS) led to faster recovery from negative energy balance toward a positive energy balance during the first $4 \mathrm{wk}$ postpartum (Osorio et al., 2013). Supplemental Met also resulted in a tendency for a lower incidence of ketosis postpartum.

\section{Biomarkers of Muscle Mass and N Metabolism}

Creatinine is an important indicator of body muscle mass and its concentration typically decreases around parturition (Kokkonen et al., 2005; Pires et al., 2013). Although Pires et al. (2013) observed a decrease in creatinine from $4 \mathrm{wk}$ before to $7 \mathrm{wk}$ after calving, the differences reported between $4 \mathrm{wk}$ before and $2 \mathrm{wk}$ after calving were marginal. Similarly, the time effect observed for creatinine in the present study was due to
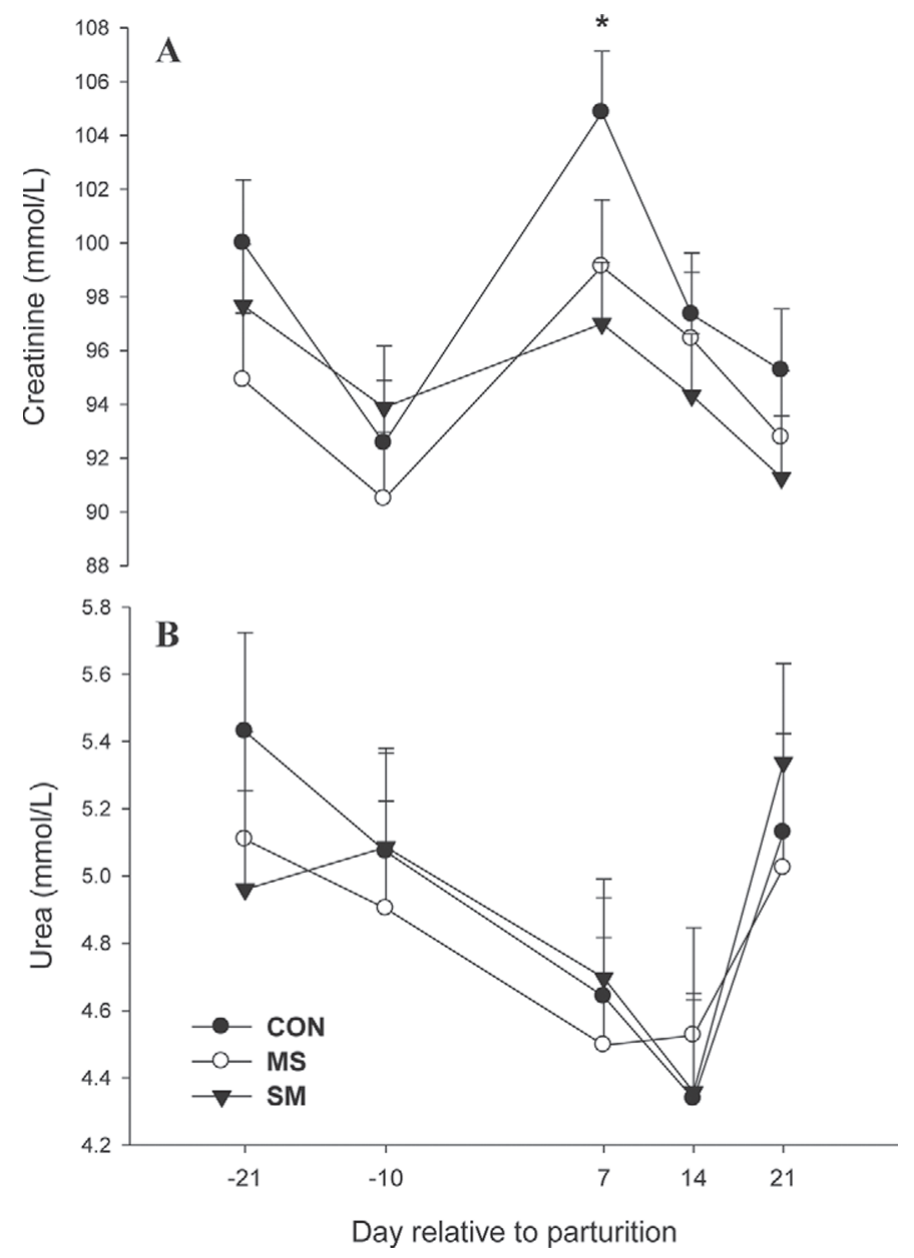

Figure 1. Effects of supplemental MetaSmart (MS; Adisseo Inc., Antony, France) or Smartamine M (SM; Adisseo Inc.) on biomarkers of muscle mass catabolism (creatinine, A) and $\mathrm{N}$ metabolism (urea, B) in dairy cows during the transition period. Mean separation between diets $(P<0.05)$ was evaluated via contrast: control $(\mathrm{CON})$ versus $\mathrm{SM}(*)$.

a marginal decrease in concentration of $4.6 \%$ from $3 \mathrm{wk}$ before to 3 wk relative to calving (Figure 1A). Thus, although cows normally experience a decrease in $\mathrm{BW}$ coupled with a decrease in both BCS and MP balance after calving, the decrease in creatinine concentration is more likely to occur during extended periods $(>4$ wk) of negative energy balance or negative MP balance. Bell et al. (2000) estimated that within a week after calving, cows are at least $600 \mathrm{~g} / \mathrm{d}$ deficient in MP. It appears that creatinine might not be sensitive enough to rapid changes in MP status. Pires et al. (2013) also observed that cows with a low BCS $(\leq 2.5)$ had lower creatinine concentration compared with medium and high BCS $(\geq 2.75)$ cows. We observed a similar effect in CON cows, which had a greater postpartum BCS than MS and SM cows (Osorio et al., 2013), and also 
Table 2. Effects of supplementing cows with MetaSmart (MS; Adisseo Inc., Antony, France) or Smartamine M (SM; Adisseo Inc.) during the pre- and postpartum periods on blood inflammation and acute phase protein biomarkers

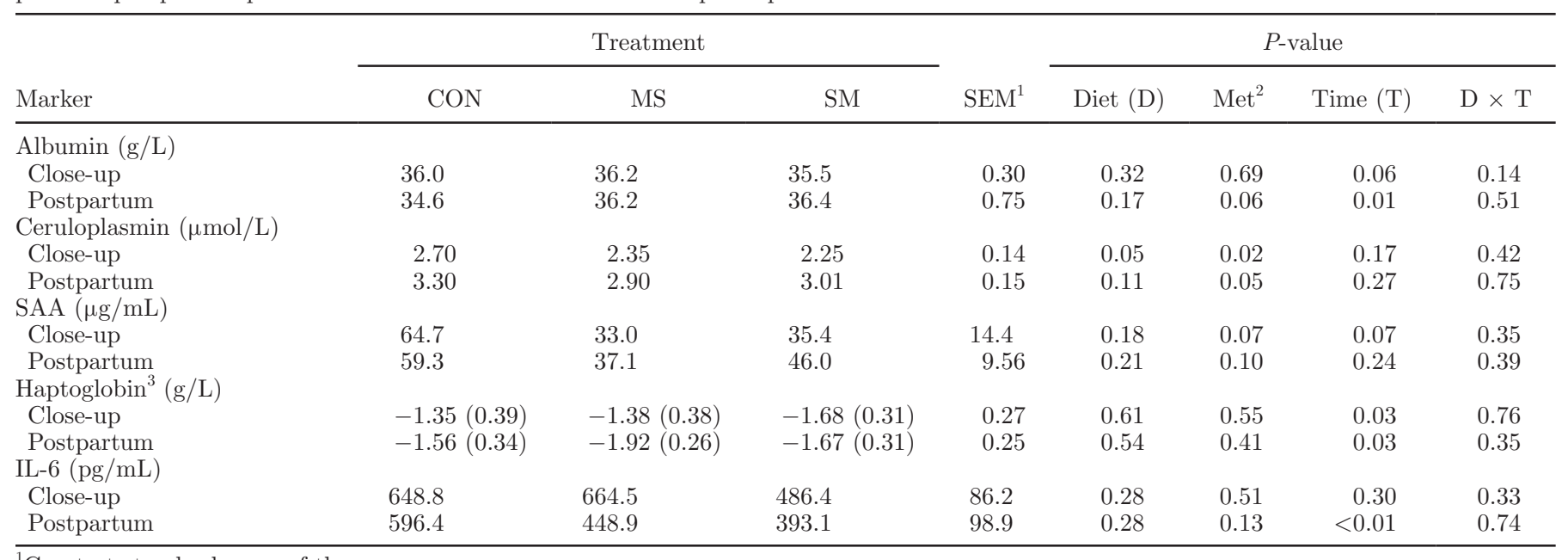

${ }^{1}$ Greatest standard error of the mean.

${ }^{2}$ Contrast statement of control (CON) vs. MS+SM.

${ }^{3}$ Data were log-transformed before statistics. Back-transformed least squares means are shown in parentheses. The standard error of the means associated with log-transformed data are in log scale.

greater creatinine concentration (Figure 1A) at $7 \mathrm{~d}$ postpartum.

\section{Biomarkers of Liver Function}

The fact that albumin is classified as a negAPP implies that hepatic production (the main site in the body) is commonly decreased during the onset of inflammation (Bertoni et al., 2008). Therefore, the substantial decrease of albumin in CON cows after calving compared with MS and SM cows (Table 2) is consistent with those animals experiencing more pronounced inflammatory conditions. The concentration of plasma negAPP such as albumin, retinol-binding protein, and total cholesterol in plasma have been used previously to classify liver function into upper, upper-intermediate, lower-intermediate, and lower quartiles (Bionaz et al., 2007; Bertoni et al., 2008). Cows in the upper postpartal liver function quartile have albumin concentrations ranging between 33 and $35 \mathrm{~g} / \mathrm{L}$ (Bionaz et al., 2007; Bertoni et al., 2008). In the current experiment, albumin concentration in Met-supplemented cows albumin was above $35 \mathrm{~g} / \mathrm{L}$ throughout the peripartal period (Figure 2A). Although albumin in CON cows was within physiological levels, the concentration decrease of $\sim 2$ $\mathrm{g} / \mathrm{L}$ from prepartum to $7 \mathrm{~d}$ postpartum was similar to that observed by Bionaz et al. (2007) for cows in the lower liver function group. Furthermore, the fact that albumin in CON cows remained lower than prepartal levels for $\sim 2$ wk was suggestive of additional liver damage during this time.
During an acute phase response (APR), Cys is released from skeletal muscle protein and used not only for synthesis of APP such as albumin (Reeds et al., 1994) but also for synthesis of glutathione (Malmezat et al., 2000). The latter suggests that unless Cys or Cys precursors (e.g., Met) are adequate in the diet, it is likely to be a limiting nutrient during the APR. Because Met is an upstream precursor of Cys through the transsulfuration pathway, it has been suggested that Met plays an important role during the APR $(\mathrm{Lu}$, 2009). In fact, Litvak et al. (2013) observed a significant decrease in albumin concentration (38.3 vs 33.7 $\mathrm{g} / \mathrm{L}$ ) in growing pigs fed a Met-deficient diet before and after an APR was induced via intramuscular injection of Escherichia coli LPS. In contrast, albumin remained unchanged in pigs fed adequate amounts of Met before and after APR induction. Taking the above findings together, it is likely that inflammatory conditions create a deregulation in the normal requirements of AA, and especially an AA such as Cys, which can be prevented or ameliorated by the supply of upstream precursors such as Met.

The increase in GOT (57.6 vs. 119.7 U/L; Figure $2 \mathrm{C})$ across treatments from -21 to $21 \mathrm{~d}$ postpartum is, to some extent, consistent with the increase of GGT (38.8\%; Figure 2E) in all groups. Although GGT concentration tended to be greater in SM than in CON and MS cows after calving, the concentration of GOT increased at a lower rate after calving in SM cows. However, this lack of a diet effect could be partly explained by transient effects due to animal variation rather than 

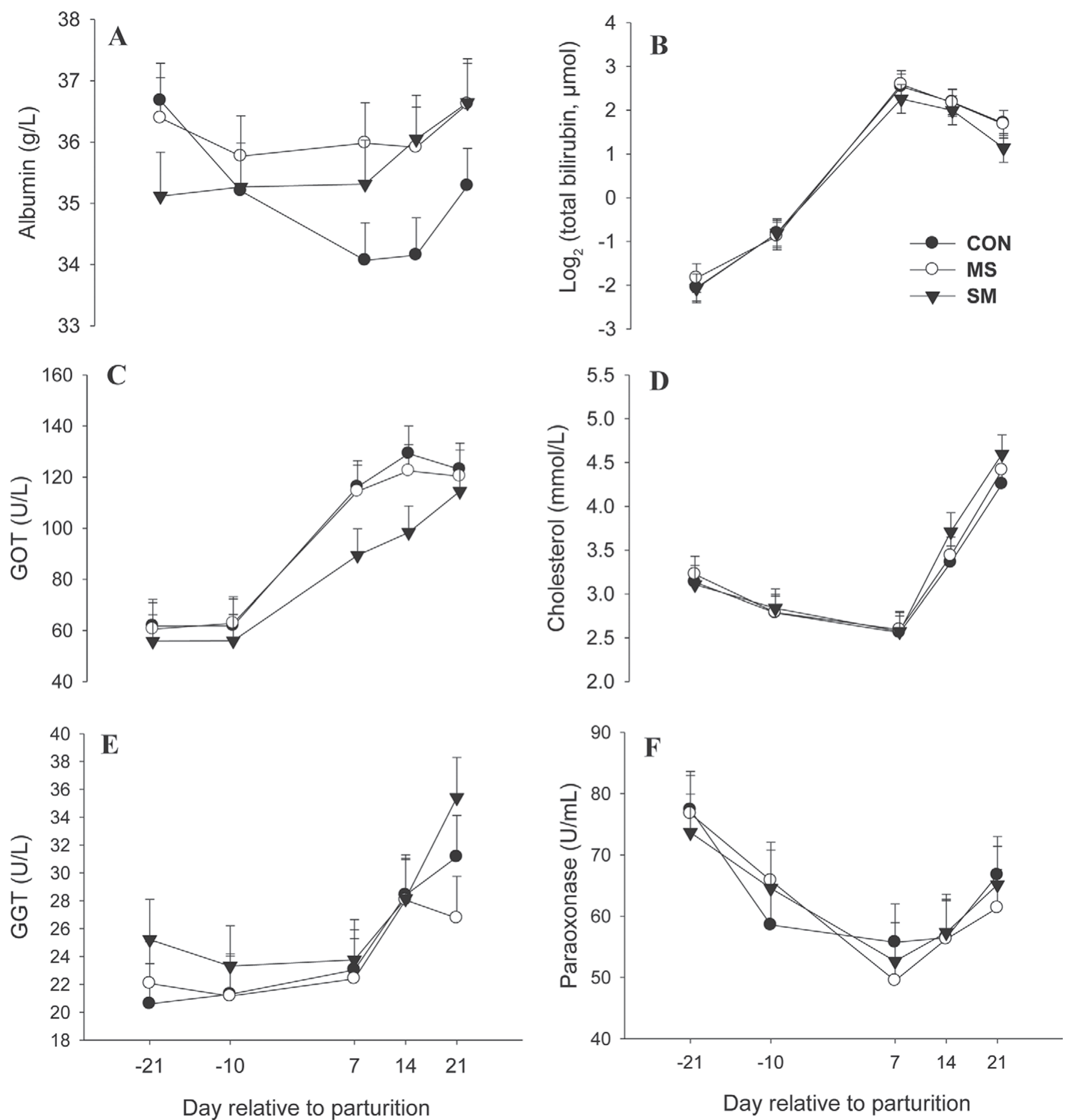

Figure 2. Effects of supplemental MetaSmart (MS; Adisseo Inc., Antony, France) or Smartamine M (SM; Adisseo Inc.) on biomarkers of liver function in dairy cows during the transition period. Albumin (A), bilirubin (B), glutamic-oxalacetic transaminase (GOT, C), cholesterol (D), $\gamma$-glutamyl transferase $(\mathrm{GGT}, \mathrm{E})$, and paraoxonase $(\mathrm{PON}, \mathrm{F})$. Mean separation between diets $(P<0.05)$ was evaluated via contrast: control $(\mathrm{CON})$ versus $\mathrm{MS}+\mathrm{SM}(*)$.

an actual treatment effect. Although this might suggest that liver damage in SM cows was more severe, it is well known that the concentrations of both enzymes (GOT and GGT) in blood increase after calving (Bertoni et al., 2008; Graugnard et al., 2012). Overall, the concentrations of GOT and GGT postpartum were within the 

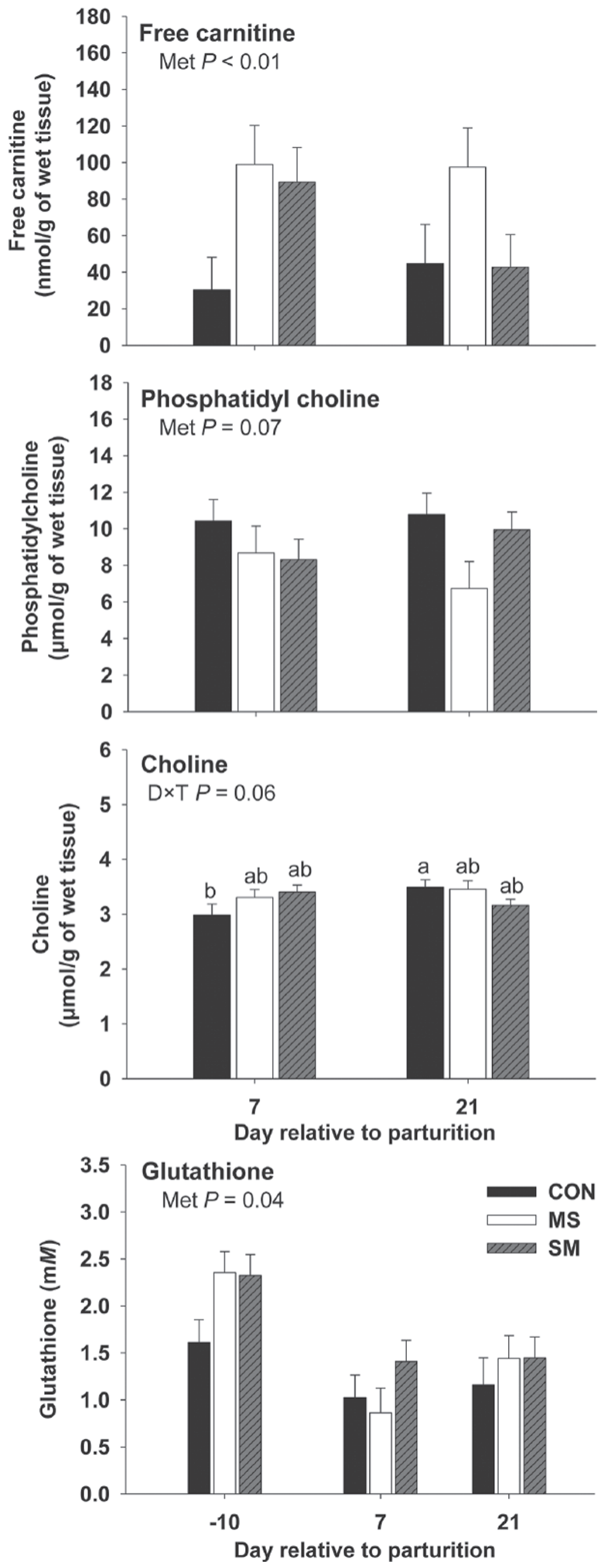

Figure 3. Effects of supplemental MetaSmart (MS; Adisseo Inc., Antony, France) or Smartamine M (SM; Adisseo Inc.) on biomarkers of energy balance and Met metabolism in dairy cows during the transition period. ${ }^{\text {a-c }}$ Differences between means in liver choline $(P<0.05)$ from an overall diet $(\mathrm{D}) \times$ time $(\mathrm{T})$ trend $(P=0.06)$. Met $=$ overall contrast: control $(\mathrm{CON})$ versus $\mathrm{MS}+\mathrm{SM}$. typical range expected for early postpartal cows without clinical disease (Bertoni et al., 2008; Graugnard et al., 2012).

The decrease in PON around parturition and specifically at $7 \mathrm{~d}$ postpartum (Figure $2 \mathrm{~F}$ ) is in agreement with previous work (Bionaz et al., 2007; Grossi et al., 2013). The decrease in serum PON at the end of pregnancy and after calving has been functionally linked to liver dysfunction due to the reduction of HDL cholesterol, which is the main carrier of paraoxonase molecules in blood (Turk et al., 2005), and that is explained by inflammation and oxidative stress (Bionaz et al., 2007).

\section{Biomarkers of Energy Balance and Met Metabolism}

During the transition period cows will normally experience an increase in adipose tissue lipolysis due to changes in hormones such as insulin and growth hormone; consequently, blood NEFA increase. As the concentration of NEFA increases around calving or in early lactation, more NEFA are taken up by the liver (Loor et al., 2013b). Subsequently, NEFA can be oxidized to provide energy to the liver, partially oxidized to produce ketone bodies, or esterified to TAG. A major site within hepatocytes for NEFA oxidation is the mitochondria, and carnitine is essential for transport of NEFA from cytosol into mitochondria for subsequent $\beta$-oxidation (Drackley, 1999). Carnitine is derived endogenously from trimethyllysine (TML); in turn, TML supply is driven by turnover of proteins containing Lys and Met, where Lys serves as the backbone while Met is the methyl donor for TML synthesis (Carlson et al., 2007b).

The greater hepatic concentration of free carnitine (82.1 vs. $37.5 \mathrm{nmol} / \mathrm{g}$ of tissue) in Met-supplemented cows (Table 1) indicates a greater bioavailability of Met to methylate Lys. Interestingly, when comparing our results with those obtained by Carlson et al. (2007a), who measured free carnitine in liver, our Met-supplemented cows had greater ( 82.1 vs. $52.9 \mathrm{nmol} / \mathrm{g}$ of tissue) free carnitine than cows fed a low dose $(6 \mathrm{~g} / \mathrm{d})$ of carnitine during early lactation (2 to $28 \mathrm{~d}$ postpartum); however, liver carnitine was lower (82.1 vs. $154.4 \mathrm{nmol} / \mathrm{g}$ of tissue) in our Met-supplemented cows than in the group supplemented with a medium dose $(50 \mathrm{~g} / \mathrm{d})$ of carnitine in the previous study (Carlson et al., 2007a). In fact, Carlson et al. (2007a) observed an average carnitine of $37.3 \mathrm{nmol} / \mathrm{g}$ of tissue from 2 to $28 \mathrm{~d}$ after calving in the control group, which is comparable to the cows fed CON (37.5 nmol/g of tissue) in our experiment.

The fact that the carnitine response in CON cows mimicked that of control cows in Carlson et al. (2007a) coupled with Met-supplemented cows having carnitine concentrations falling between those fed low and me- 

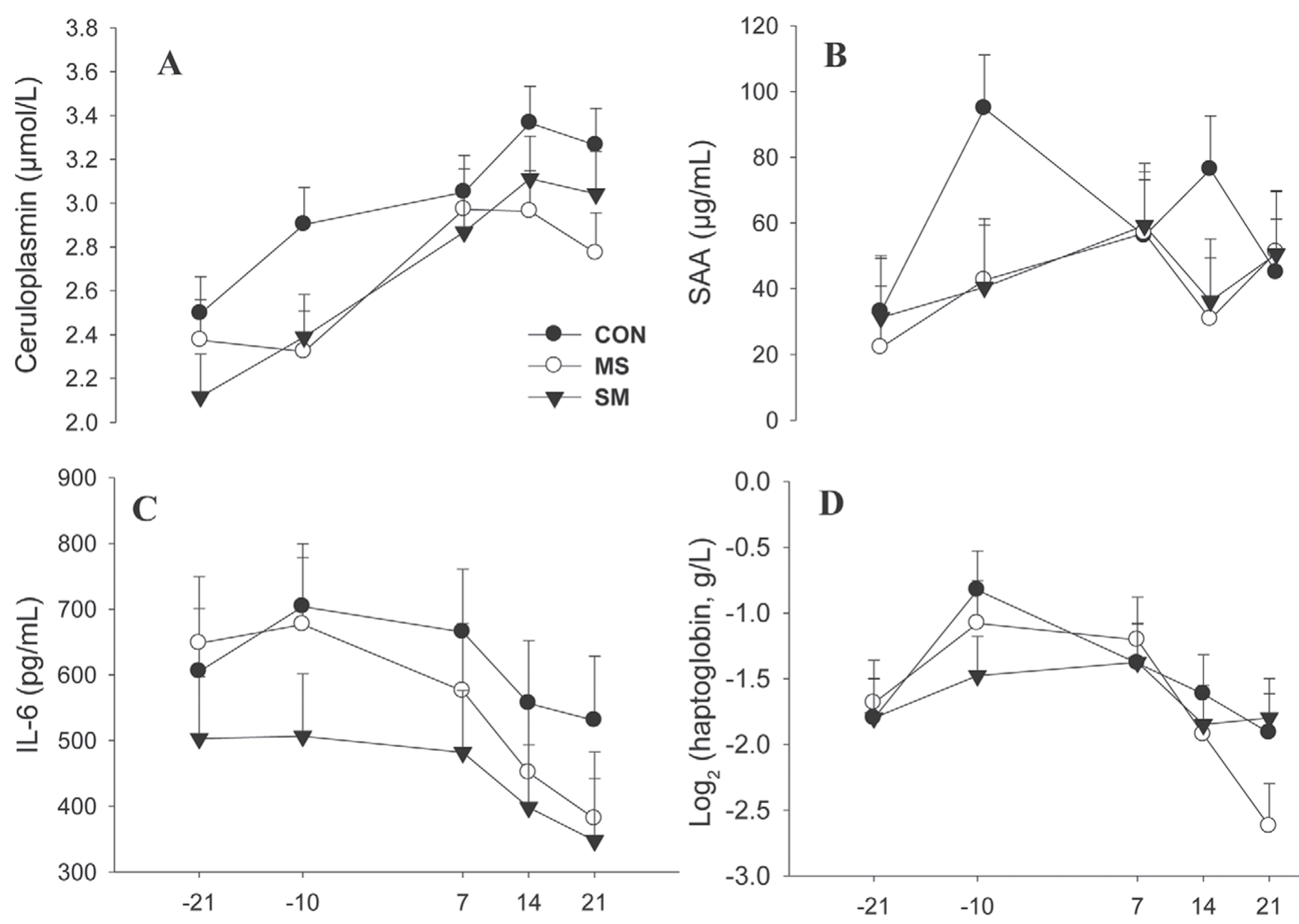

Day relative to parturition

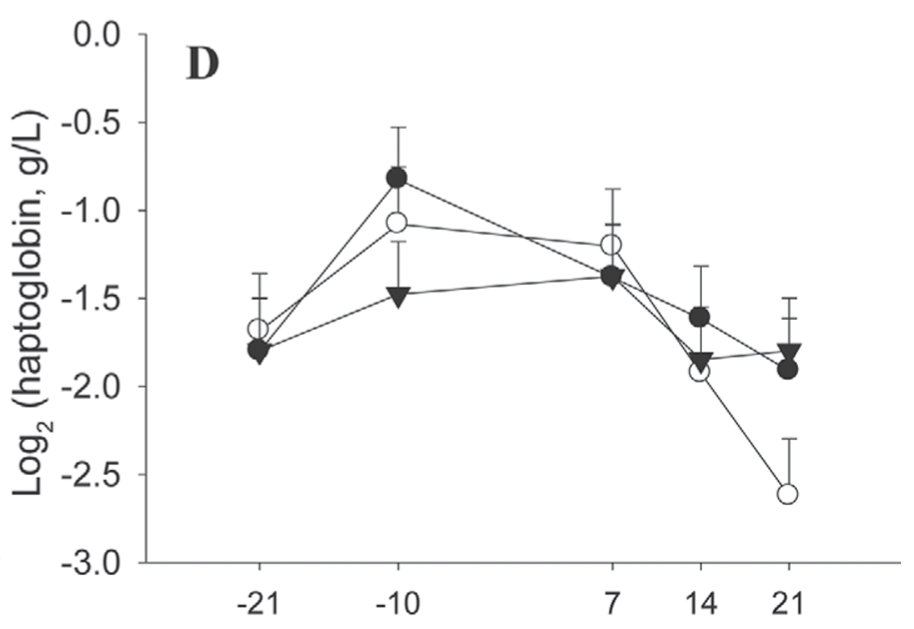

Day relative to parturition

Figure 4. Effects of supplemental MetaSmart (MS; Adisseo Inc., Antony, France) or Smartamine M (SM; Adisseo Inc.) on biomarkers of inflammation in dairy cows during the transition period. Ceruloplasmin (A), serum amyloid A (SAA, B), IL-6 (C), and haptoglobin (E). Mean separation between diets $(P<0.05)$ was evaluated via contrast: control $(\mathrm{CON})$ versus $\mathrm{MS}+\mathrm{SM}(*)$.

dium doses of carnitine strongly suggests that intrahepatic Met availability in Met-supplemented cows was large enough to spare Met to synthesize carnitine. As mentioned above, NEFA taken up by the liver can be esterified into TAG and exported into the bloodstream as VLDL, which requires apolipoprotein B (ApoB)-100, cholesterol, and PC. Although PC tended $(P=0.07)$ to be lower in Met-supplemented cows, this could suggest a greater degree of utilization of PC for the assembly or export of VLDL. In fact, we observed a trend for lower plasma concentration of ApoB-100 in CON cows (Osorio et al., 2013), suggesting that this molecule might had limited the assembly or export of VLDL from liver and consequently contributed to the buildup of $\mathrm{PC}$ in CON cows.

Previous data suggest a lipotropic effect of Met in ruminants by improving the assembly or export of VLDL (Bauchart et al., 1998) and also a lower (11.4 vs. $16.1 \%$ ) hepatic lipid content at $21 \mathrm{~d}$ postpartum in Met-supplemented cows (Osorio et al., 2013). The increase in hepatic choline in CON from 7 to $21 \mathrm{~d}$ (Figure 3) could be associated with greater hydrolysis of PC into phosphatidic acid and choline via phospholipase D. In fact, the greater $\mathrm{PC}$ in $\mathrm{CON}$ cows might have promoted this effect.

The lower milk choline in Met-supplemented cows could be related to greater utilization of hepatic PC for VLDL than for choline synthesis. The fact that free milk choline measured in our experiment was considerably lower (31.2 vs. $114.7 \mathrm{mg} / \mathrm{L}$ ) than total milk choline published previously (Deuchler et al., 1998; Elek et al., 2008) indicates that choline is an abundant component of other intermediate metabolites such as acetylcholine, lysophosphatidylcholine, and PC. In fact, Elek et al. (2008) observed a significant increase of total milk choline over the first $60 \mathrm{~d}$ postpartum, which suggests 

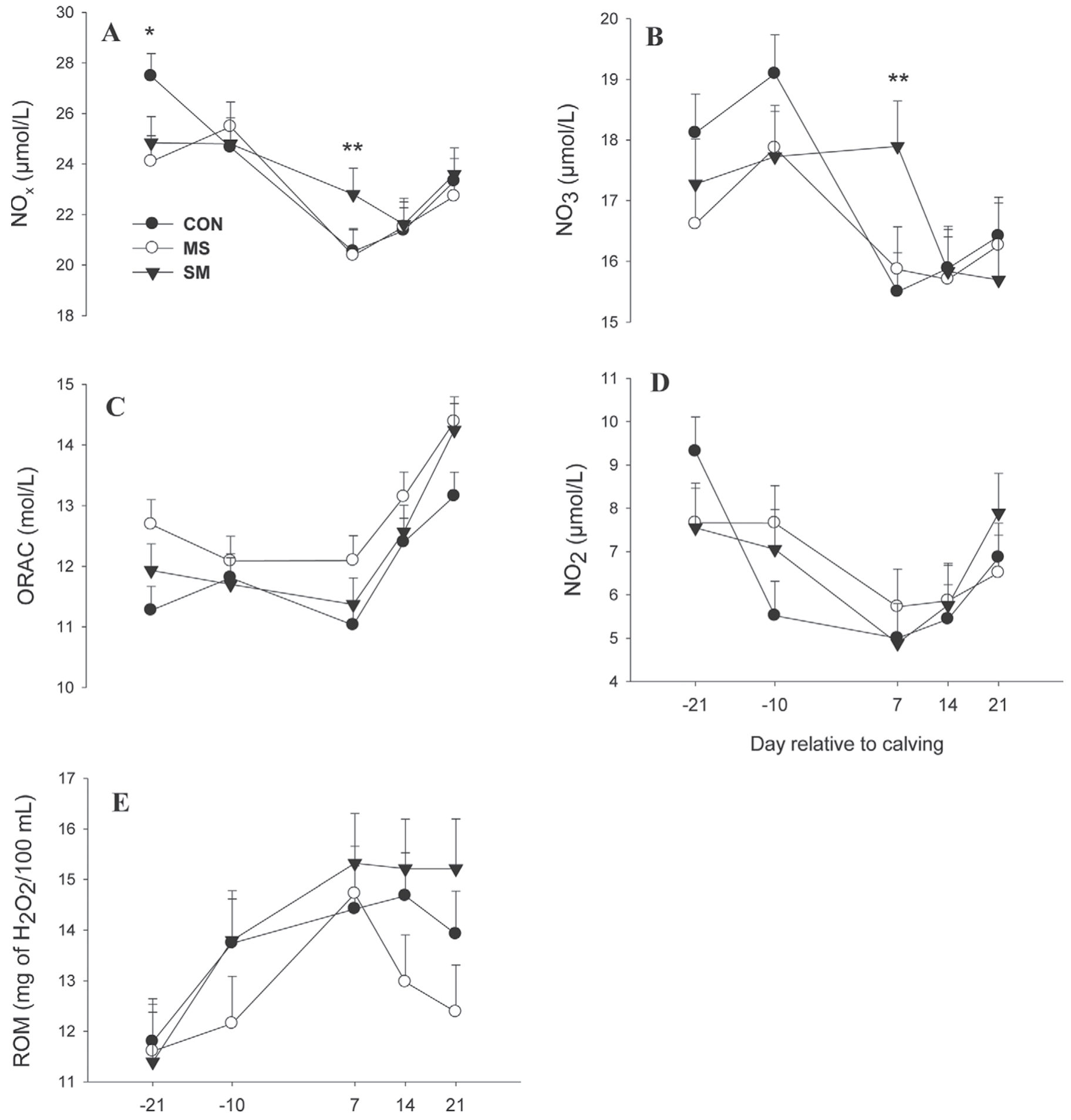

Day relative to calving

Figure 5. Effects of supplemental MetaSmart (MS; Adisseo Inc., Antony, France) or Smartamine M (SM; Adisseo Inc.) on biomarkers of oxidative stress in dairy cows during the transition period. Nitric oxide ( $\mathrm{NOx}, \mathrm{A})$, nitrate $\left(\mathrm{NO}_{3}{ }^{-}, \mathrm{B}\right)$, oxygen radical absorbance capacity (ORAC, C), nitrite $\left(\mathrm{NO}_{2}{ }^{-}, \mathrm{D}\right)$, reactive oxygen metabolites (ROM, E), and liver tissue total glutathione $(\mathrm{F})$. Mean separation between diets $(P<0.05)$ were evaluated via contrast: control $(\mathrm{CON})$ versus $\mathrm{MS}+\mathrm{SM}\left({ }^{*}\right)$ and $\mathrm{CON}$ versus $\mathrm{SM}(* *)$. 

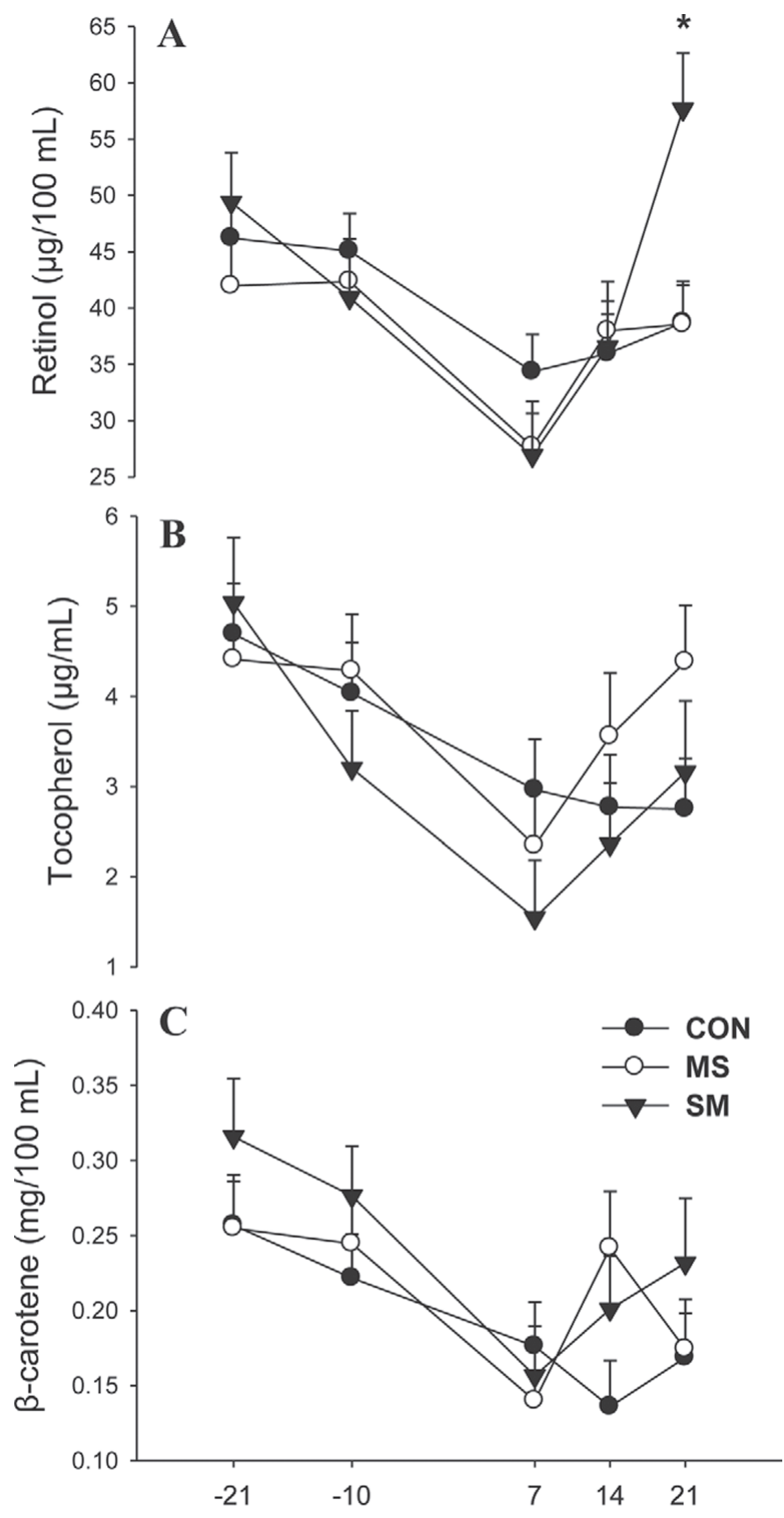

Day relative to parturition

Figure 6. Effects of supplemental MetaSmart (MS; Adisseo Inc., Antony, France) or Smartamine M (SM; Adisseo Inc.) on concentration of vitamins in dairy cows during the transition period. Mean separation between diets $(P<0.05)$ was evaluated via contrast: control $(\mathrm{CON})$ versus $\mathrm{SM}(*)$.

that, as cows progress through early lactation, the PC available is redirected into choline rather than VLDL synthesis. Such a hypothesis is supported by the fact that as lactation progresses, the need to export lipid out of the liver decreases.

\section{Biomarkers of Inflammation and APP}

Concentrations of ceruloplasmin and SAA are likely to increase during inflammatory episodes such as those occurring in the peripartal period (Ceciliani et al., 2012). Although ceruloplasmin was not affected by the $\mathrm{D} \times \mathrm{T}$ interaction, it was $10.7 \%$ lower (Table 1 ) in Metsupplemented diets, which was more noticeable at -10 d prepartum (Figure 4A). Despite the lack of time effect for the concentration of SAA, most of the $30.9 \%$ increase in CON cows compared with Met-supplemented cows could be attributed to trends for greater concentrations of SAA in CON cows during the close-up $(P=0.07)$ and postpartum $(P=0.10$; Table 2$)$ periods. Although IL-6 was not directly affected by Met supplementation (Table 1), the tendency $(P=0.13)$ for lower postpartal IL-6 concentration in Met-supplemented cows than CON could be taken as indication that supplemental Met decreased the synthesis of this proinflammatory cytokine after calving. The latter could have elicited an effect on the liver, effectively reducing the production of posAPP such as ceruloplasmin and SAA.

It could be envisioned that any factor reducing the synthesis of posAPP by the liver would spare some AA for the synthesis of negAPP and perhaps for utilization by the mammary gland. Under such a scenario, supplemental SM and MS would have increased Met availability to the mammary gland (more than otherwise expected) and partly explain the greater overall production of milk and ECM (Osorio et al., 2013). Similar effects have been observed in chickens when they are raised under stressful environments that induce both an immune response and partitioning of nutrients (e.g., Lys and Met) toward immune cells (e.g., increasing IL1; Klasing and Barnes, 1988). The expected end result is a reduction in the AA requirements for growth and tissue accretion.

\section{Biomarkers of Oxidative Stress}

The total $\mathrm{NO}_{2}{ }^{-}$and $\mathrm{NO}_{3}{ }^{-}$concentration is a valid estimation of $\mathrm{NOx}$ generation in biological samples (Komine et al., 2004). The similar profiles in the concentration of NOx (Figure 5A), $\mathrm{NO}_{2}^{-}$(Figure 5D), and $\mathrm{NO}_{3}{ }^{-}$(Figure $5 \mathrm{~B}$ ) agree with the proposed definition of NOx. We are unaware of previous studies reporting the pattern of NOx concentration in blood around calving. However, milk secretions sampled at 4-wk intervals during the dry period and throughout lactation had greater concentrations of NOx prepartum than postpartum (Bastan et al., 2013), a finding similar to our results in blood.

Previous work with dairy cows demonstrated that NOx is a potent vasodilatory compound that can be 
produced locally by the mammary gland (Prosser et al., 1996). In turn, an increase in local $\mathrm{NOx}$ and $\mathrm{NO}_{3}{ }^{-}$ could increase the flow and mammary uptake of fatty acids and AA for milk synthesis (Bastan et al., 2013). Therefore, the greater concentration of NOx in SM at 7 $\mathrm{d}$ is suggestive of a mechanistic role in the substantial increase in milk production $(+2.7 \mathrm{~kg} / \mathrm{d}$ greater than $\mathrm{CON})$, fat yield $(+0.48 \mathrm{~kg} / \mathrm{d}$ greater than $\mathrm{CON})$, and protein yield $(+0.33 \mathrm{~kg} / \mathrm{d}$ greater than $\mathrm{CON})$ observed in SM cows within the first week of lactation (Osorio et al., 2013). The fact that cows supplemented with MS did not have greater NOx concentrations but had similar performance as SM cows complicates the interpretation of NOx as a biological effector of milk synthesis. Further research could help clarify the link between rumen-protected Met, NOx, and local effects on the mammary gland.

The ORAC capacity was $5.9 \%$ greater in Met-supplemented cows, which could have been affected at least in part by the greater $(22.6 \%)$ liver glutathione concentration and the greater concentration of vitamins such as retinol (Figure 6A) and $\beta$-carotene (Supplemental Table S1; http://dx.doi.org/10.3168/jds.2013-7679). The total liver glutathione effect can be directly associated with Met supplementation because Met can be incorporated upstream in the pathway for de novo glutathione synthesis (Halsted, 2013). The time effect observed for liver glutathione could be mainly attributed to greater prepartal concentration in Met-supplemented cows that eventually decreased as lactation progressed (Figure 3). In mice, liver glutathione has been described as a reservoir for supplying AA such as Cys to the $\gamma$-glutamyl cycle (Lu, 2009). Glutathione in dairy cows can supply AA such as Cys to the mammary gland for milk synthesis (Pocius et al., 1981). In fact, Pocius et al. (1981) observed a low uptake of free plasma Cys by mammary gland, which indicated that glutathione might be an important source of Cys, because substantial uptake of glutathione by the mammary gland was observed. Taken together, it is plausible that the accumulation of glutathione in liver during the close-up period in cows fed MS and SM served, after calving, as a "buffer" to spare Cys to promote milk synthesis, which was reflected by the greater milk component production, milk protein percentage, and milk yield (Osorio et al., 2013).

The overall increase in ROM from pre- to postpartum deviates slightly from findings observed previously by Bionaz et al. (2007) and Trevisi et al. (2009), where ROM concentration peaked at $7 \mathrm{~d}$ postpartum and decreased substantially by $28 \mathrm{~d}$. Despite the lack of a $\mathrm{D} \times \mathrm{T}$ interaction, compared with $\mathrm{CON}$ and $\mathrm{SM}$, there was an evident reduction $(15.6 \%)$ of ROM in MS from 7 to $21 \mathrm{~d}$ postpartum (Figure 5E). These results, coupled with the greater postpartal neutrophil activity in Met-supplemented cows (Osorio et al., 2013), indicate that $\mathrm{ROM}$ concentration was not entirely driven by concentrations of $\mathrm{O}_{2}{ }^{-}$and $\mathrm{H}_{2} \mathrm{O}_{2}$ (e.g., produced during phagocytosis). Other underlying factors, such as changes in NADH/NADPH oxidase, xanthine oxidase, and arachidonic acid metabolism, might control overall oxidative status (Cepinskas et al., 2002).

It could also be hypothesized that cows fed MS might have relied on other antioxidant sources such as vitamin $\mathrm{E}$ in the form of tocopherol or SOD to neutralize and lessen ROM levels arising from oxidative stress around parturition (Bionaz et al., 2007). Increases in the concentration of tocopherol of $91.3 \%$ and $106 \%$ between 7 and $21 \mathrm{~d}$ postpartum in cows fed MS and SM support its use as an antioxidant. It has been observed previously that postpartal activity of SOD is lower, particularly in cows with greater BCS before calving (Bernabucci et al., 2005). Taking that and the lower postpartal BCS in Met-supplemented cows (Osorio et al., 2013) into account, SOD activity might have influenced, in part, the reduction of ROM in MS cows after $7 \mathrm{~d}$ postpartum. Although this idea should also hold for SM cows, it is possible that rates of BCS loss postpartum (Bernabucci et al., 2005) or reduction in zinc and copper availability (Muehlenbein et al., 2001) after calving influenced SOD activity in SM cows.

\section{Vitamins}

Overall, the decrease in concentration of vitamins (Figure 6) from prepartum to $7 \mathrm{~d}$ postpartum is similar to results observed by Graugnard et al. (2012). The sharp increase from 7 to $21 \mathrm{~d}$ in concentrations of retinol and tocopherol are in agreement with Bertoni et al. (2008). Moreover, those increases in retinol and tocopherol were particularly evident in the Met-supplemented cows (Figure 6A and 6B). Thus, our results agree with previous data that feeding methyl-deficient (choline and folate) diets leads to a reduction of vitamin concentrations (ascorbic acid, $\alpha$ - and $\gamma$-tocopherol, and retinol) in tissues (i.e., lung, liver, and heart) and plasma (Henning et al., 1997).

In the case of $\alpha$-tocopherol, Henning et al. (1997) attributed those effects to disturbances in VLDL synthesis (as a result of feeding choline-deficient diets) coupled with FA and TAG accumulation in liver. The latter can affect the hepatic transport of $\alpha$-tocopherol in the VLDL (Jenkins et al., 1993; Henning et al., 1997). Jenkins et al. (1993) attributed a decrease in plasma retinol to an impairment of the release or transport of retinol in the blood via retinol-binding proteins. From the above discussion, it can be suggested that cows fed 
SM might have had greater ability to export or transport retinol into the bloodstream at $21 \mathrm{~d}$ postpartum (Figure 6A).

\section{CONCLUSIONS}

Overall, the responses observed at the level of IL-6 and APP in cows supplemented with Smartamine M or MetaSmart revealed favorable alterations of the inflammatory status of cows. The greater concentration of albumin in response to Met-supplementation suggested that rumen-protected Met promoted liver function. The responses in hepatic carnitine and PC when Met was supplemented suggested greater potential for $\beta$-oxidation with a concomitant activation of the assembly or export of VLDL. Biomarker analyses in blood, milk, and tissue suggest that the beneficial effect of feeding SM or MS on postpartal cow performance is due, in part, to better immunometabolic status.

\section{ACKNOWLEDGMENTS}

The authors gratefully acknowledge Adisseo (Commentry, France) for partial financial support of this research. The authors thank Travis Michels and Mike Katterhenry of the University of Illinois Dairy Research Unit (Urbana) staff for help with animal management.

\section{REFERENCES}

Auboiron, S., D. Durand, D. Bauchart, J. C. Robert, and M. J. Chapman. 1994. Lipoprotein metabolism in the preruminant calf: Effect of a high fat diet supplemented with L-methionine. J. Dairy Sci. $77: 1870-1881$.

Auboiron, S., D. Durand, J. C. Robert, M. J. Chapman, and D. Bauchart. 1995. Effects of dietary fat and L-methionine on the hepatic metabolism of very low density lipoproteins in the preruminant calf, Bos spp. Reprod. Nutr. Dev. 35:167-178.

Aviram, M., and M. Rosenblat. 2004. Paraoxonases 1, 2, and 3, oxidative stress, and macrophage foam cell formation during atherosclerosis development. Free Radic. Biol. Med. 37:1304-1316.

Bastan, A., M. Cengiz, S. Cengiz, T. Sel, B. Polat, A. Colak, M. Akan, and I. Darbaz. 2013. Nitric oxide concentrations in mammary quarters during heifer mastitis. Animal 7:499-504.

Bauchart, D., D. Durand, D. Gruffat, and Y. Chilliard. 1998. Mechanism of liver steatosis in early lactation cows: Effects of hepatoprotector agents. Pages 49-56 in Proc. Cornell Nutr. Conf. Feed Manuf. Cornell University, Ithaca, NY.

Bell, A. W., W. S. Burhans, and T. R. Overton. 2000. Protein nutrition in late pregnancy, maternal protein reserves and lactation performance in dairy cows. Proc. Nutr. Soc. 59:119-126.

Bernabucci, U., B. Ronchi, N. Lacetera, and A. Nardone. 2005. Influence of body condition score on relationships between metabolic status and oxidative stress in periparturient dairy cows. J. Dairy Sci. 88:2017-2026.

Bertoni, G., E. Trevisi, X. Han, and M. Bionaz. 2008. Effects of inflammatory conditions on liver activity in puerperium period and consequences for performance in dairy cows. J. Dairy Sci. 91:3300-3310.

Bionaz, M., E. Trevisi, L. Calamari, F. Librandi, A. Ferrari, and G. Bertoni. 2007. Plasma paraoxonase, health, inflammatory condi- tions, and liver function in transition dairy cows. J. Dairy Sci. 90:1740-1750.

Cao, G., and R. L. Prior. 1999. Measurement of oxygen radical absorbance capacity in biological samples. Methods Enzymol. 299:5062.

Carlson, D. B., J. W. McFadden, A. D'Angelo, J. C. Woodworth, and J. K. Drackley. 2007a. Dietary L-carnitine affects periparturient nutrient metabolism and lactation in multiparous cows. J. Dairy Sci. 90:3422-3441.

Carlson, D. B., J. C. Woodworth, and J. K. Drackley. 2007b. Effect of L-carnitine infusion and feed restriction on carnitine status in lactating Holstein cows. J. Dairy Sci. 90:2367-2376.

Ceciliani, F., J. J. Ceron, P. D. Eckersall, and H. Sauerwein. 2012. Acute phase proteins in ruminants. J. Proteomics 75:4207-4231.

Cepinskas, G., T. Rui, and P. R. Kvietys. 2002. Interaction between reactive oxygen metabolites and nitric oxide in oxidant tolerance. Free Radic. Biol. Med. 33:433-440.

Dann, H. M., N. B. Litherland, J. P. Underwood, M. Bionaz, A. D'Angelo, J. W. McFadden, and J. K. Drackley. 2006. Diets during far-off and close-up dry periods affect periparturient metabolism and lactation in multiparous cows. J. Dairy Sci. 89:3563-3577.

Deuchler, K. N., L. S. Piperova, and R. A. Erdman. 1998. Milk choline secretion as an indirect indicator of postruminal choline supply. J. Dairy Sci. 81:238-242.

Drackley, J. K. 1999. ADSA Foundation Scholar Award. Biology of dairy cows during the transition period: The final frontier? J. Dairy Sci. 82:2259-2273.

Durand, D., Y. Chilliard, and D. Bauchart. 1992. Effect of lysine and methionine on in vivo hepatic secretion of VLDL in dairy cow. J. Dairy Sci. 75(Suppl. 1):279. (Abstr.)

Elek, P., J. R. Newbold, T. Gaal, L. Wagner, and F. Husveth. 2008. Effects of rumen-protected choline supplementation on milk production and choline supply of periparturient dairy cows. Animal $2: 1595-1601$.

Graugnard, D. E., M. Bionaz, E. Trevisi, K. M. Moyes, J. L. SalakJohnson, R. L. Wallace, J. K. Drackley, G. Bertoni, and J. J. Loor. 2012. Blood immunometabolic indices and polymorphonuclear neutrophil function in peripartum dairy cows are altered by level of dietary energy prepartum. J. Dairy Sci. 95:1749-1758.

Grossi, P., G. Bertoni, F. P. Cappelli, and E. Trevisi. 2013. Effects of the precalving administration of omega-3 fatty acids alone or in combination with acetylsalicylic acid in periparturient dairy cows. J. Anim. Sci. 91:2657-2666.

Haeggström, J. Z., and C. D. Funk. 2011. Lipoxygenase and leukotriene pathways: Biochemistry, biology, and roles in disease. Chem. Rev. 111:5866-5898.

Halsted, C. H. 2013. B-Vitamin dependent methionine metabolism and alcoholic liver disease. Clin. Chem. Lab. Med. 51:457-465.

Henning, S. M., M. E. Swendseid, B. T. Ivandic, and F. Liao. 1997. Vitamins C, E and A and heme oxygenase in rats fed methyl/ folate-deficient diets. Free Radic. Biol. Med. 23:936-942.

Jenkins, M. Y., N. M. Sheikh, G. V. Mitchell, E. Grundel, S. R. Blakely, and C. J. Carter. 1993. Dietary carotenoids influenced biochemical but not morphological changes in adult male rats fed a choline-deficient diet. Nutr. Cancer 19:55-65.

Kass, S. U., D. Pruss, and A. P. Wolffe. 1997. How does DNA methylation repress transcription? Trends Genet. 13:444-449.

Kindt, T. J., R. A. Goldsby, B. A. Osborne, and J. Kuby. 2007. Kuby Immunology. 6th ed. W. H. Freeman, New York, NY.

Klasing, K. C., and D. M. Barnes. 1988. Decreased amino acid requirements of growing chicks due to immunologic stress. J. Nutr. 118:1158-1164.

Kokkonen, T., J. Taponen, T. Anttila, L. Syrjala-Qvist, C. Delavaud, Y. Chilliard, M. Tuori, and A. T. Tesfa. 2005. Effect of body fatness and glucogenic supplement on lipid and protein mobilization and plasma leptin in dairy cows. J. Dairy Sci. 88:1127-1141.

Komine, K., T. Kuroishi, Y. Komine, K. Watanabe, J. Kobayashi, T. Yamaguchi, S. Kamata, and K. Kumagai. 2004. Induction of nitric oxide production mediated by tumor necrosis factor alpha on staphylococcal enterotoxin C-stimulated bovine mammary gland cells. Clin. Diagn. Lab. Immunol. 11:203-210. 
LeBlanc, S. J. 2012. Interactions of metabolism, inflammation, and reproductive tract health in the postpartum period in dairy cattle. Reprod. Domest. Anim. 47(Suppl. 5):18-30.

Litvak, N., A. Rakhshandeh, J. K. Htoo, and C. F. de Lange. 2013. Immune system stimulation increases the optimal dietary methionine to methionine plus cysteine ratio in growing pigs. J. Anim. Sci. 91:4188-4196.

Loor, J. J., G. Bertoni, A. Hosseini, J. R. Roche, and E. Trevisi. 2013a. Functional welfare-Using biochemical and molecular technologies to understand better the welfare state of peripartal dairy cattle. Anim. Prod. Sci. 53:931-953.

Loor, J. J., M. Bionaz, and J. K. Drackley. 2013b. Systems physiology in dairy cattle: Nutritional genomics and beyond. Annu. Rev. Anim.Biosci. 1:365-392.

Lu, S. C. 2009. Regulation of glutathione synthesis. Mol. Aspects Med. 30:42-59.

Malmezat, T., D. Breuille, P. Capitan, P. P. Mirand, and C. Obled. 2000. Glutathione turnover is increased during the acute phase of sepsis in rats. J. Nutr. 130:1239-1246.

Martinov, M. V., V. M. Vitvitsky, R. Banerjee, and F. I. Ataullakhanov. 2010. The logic of the hepatic methionine metabolic cycle. Biochim. Biophys. Acta 1804:89-96.

Muehlenbein, E. L., D. R. Brink, G. H. Deutscher, M. P. Carlson, and A. B. Johnson. 2001. Effects of inorganic and organic copper supplemented to first-calf cows on cow reproduction and calf health and performance. J. Anim. Sci. 79:1650-1659.

O’Boyle, N., C. M. Corl, J. C. Gandy, and L. M. Sordillo. 2006. Relationship of body condition score and oxidant stress to tumor necrosis factor expression in dairy cattle. Vet. Immunol. Immunopathol. 113:297-304.
Osorio, J. S., P. Ji, J. K. Drackley, D. Luchini, and J. J. Loor. 2013 Supplemental Smartamine M or MetaSmart during the transition period benefits postpartal cow performance and blood neutrophil function. J. Dairy Sci. 96:6248-6263.

Pires, J. A., C. Delavaud, Y. Faulconnier, D. Pomies, and Y. Chilliard. 2013. Effects of body condition score at calving on indicators of fat and protein mobilization of periparturient Holstein-Friesian cows. J. Dairy Sci. 96:6423-6439.

Pocius, P. A., J. H. Clark, and C. R. Baumrucker. 1981. Glutathione in bovine blood: Possible source of amino acids for milk protein synthesis. J. Dairy Sci. 64:1551-1554.

Prosser, C. G., S. R. Davis, V. C. Farr, and P. Lacasse. 1996. Regulation of blood flow in the mammary microvasculature. J. Dairy Sci. 79:1184-1197.

Reeds, P. J., C. R. Fjeld, and F. Jahoor. 1994. Do the differences between the amino acid compositions of acute-phase and muscle proteins have a bearing on nitrogen loss in traumatic states? J. Nutr. 124:906-910.

Trevisi, E., M. Amadori, A. M. Bakudila, and G. Bertoni. 2009. Metabolic changes in dairy cows induced by oral, low-dose interferonalpha treatment. J. Anim. Sci. 87:3020-3029.

Trevisi, E., M. Amadori, S. Cogrossi, E. Razzuoli, and G. Bertoni. 2012. Metabolic stress and inflammatory response in high-yielding, periparturient dairy cows. Res. Vet. Sci. 93:695-704.

Turk, R., D. Juretic, D. Geres, N. Turk, B. Rekic, V. Simeon-Rudolf, M. Robic, and A. Svetina. 2005. Serum paraoxonase activity in dairy cows during pregnancy. Res. Vet. Sci. 79:15-18. 